\title{
Up Against a Wall: Europe's Options for Regulating Biotechnology Through Regulatory Anarchy
}

Entre les forts et les faibles, c'est la liberté qui supprime et c'est la loi qui libère François La Rochefoucauld

Aaron A. Ostrovsky ${ }^{*}$

\begin{abstract}
$\underline{\text { Abstract }}$
Based on the current state of EU law and the political sentiment surrounding Genetically Modified Organisms, this paper argues that the best approach to regulating the import and export of GMOs into the Community and between Member States is by what I will call for the purposes of this Paper "regulatory anarchy." This system sits in opposition to a hierarchical regulatory approach which may be associated with traditional neo-functionalist theories of Community integration. Applied in the context of GMOs, regulatory anarchy envisions integration not coming solely from Community rules conceived by the Commission, but by Member State negotiated rules accomplished at the level of regulatory civil servants negotiating among each other. Greater centralization will occur in the regulation of GMOs because the risk of defection in this area by an individual regulatory body imposes very high costs on other national regulators, to the point where they are willing to relinquish some of their own enforcement authority for assurances against collective action problems. Due to the current gridlock caused by recalcitrant Member States, the GMO regime may be more effectively and efficiently handled by a system that employs regulatory anarchy; whereby twenty-five interested parties are initially brought to the table to approve a release (rather than one Member State), leaving less opportunities for regulatory capture by one Member State and still leaving room for Community supervision.
\end{abstract}

I. Introduction 2

II. The Deliberate Release Approval Process - An Amalgam of Competences ............. 6

A. Mechanics of the Deliberate Release Directive ............................................ 7

B. Science, Policy, and the Regulatory Blockade ............................................... 11

III. Member State Options for Regulating GMOs Beyond the Approval Process .... 14

A. The Questionable Effectiveness of Member State Objections at the Community

Level of the Approval Process ............................................................................ 16

B. The Possibility for Individual Member State Prohibitions of GMOs Post Approval

- Beyond Cassis de Dijon? ........................................................................................... 19

IV. Towards a More Centralized Regulation of Biotechnology? ............................. 27

A. Neo-functionalism Reborn to Regulate Biotechnology? .................................... 28

B. Regulatory Anarchy - A Uniquely European Solution ...................................... 32

* The author would like to thank Panos Koutrakos, Daniel Halberstam, and Francesca Bignami for helpful suggestions. All mistakes and omissions belong solely to the author. 
V. Conclusion

\section{Introduction}

The regulation of genetically modified organisms (GMOs) has challenged the unification and harmonization of the European regulatory state like nothing else. In an attempt to mitigate a collision between Community and Member State interests ${ }^{1}$, Europe has devised a complex approval system whereby both Member States and Community institutions have input at discreet stages into the approval process. Despite the Member States' more limited role in the GMO approval process, they have wielded their power mightily, bringing the entire regulatory procedure to a standstill in most instances. While this has appeased environmental interests in Europe, it is by no means a regulatory solution. The question still remains as to how to organize an efficient and effective regulatory policy for biotechnology.

Despite the lack of overwhelming scientific opinion on the exact risks that GMOs pose to human health and the environment, there is no doubt that GMOs do pose some risks beyond those which convention products pose and the European marketplace has already grown accustomed to. In general, GMOs present risks to human health and to the environment. The risks GMOs pose to human health were what first captured the public's imagination, specifically that genetically modifying food would lead to "changes in allergenicity, toxicity, or nutritional composition of foods." ${ }^{2}$ Uncertainty as to the

\footnotetext{
${ }^{1}$ GMOs have been rejected as unsafe or undesirable by the majority of the European public as recorded in successive polls over the past decade. GREgORY C. SHAFFER \& MARK A. POLlack, Regulating Between National Fears and Global Disciplines: Agricultural Biotechnology in the EU 4 (Jean Monnet Working Paper 10/04, 2004).

${ }^{2}$ Robert Howse \& Petros C. Mavroidis, Europe's Evolving Regulatory Strategy for GMOs - The Issue of Consistency with WTO Law: Of Kine and Brine, 24 FORDHAM INT'L L.J. 317, 351 (2000) (quoting
} 
allergenicity of genetically modified foods led to a situation where any consumer, regardless of his or her health status, could potentially be a victim of "GMO poisoning.",3

While concerns about risks to human health are significant, arguably the biggest risks GMOs pose are to biodiversity and local, regional, and global environments. ${ }^{4}$ These risks can include: the development of superweeds where GMOs cross-breed with native species to out-compete other species and overrun whole ecosystems ${ }^{5}$; species displacement where GMOs themselves overrun native species ${ }^{6}$; and unintentional effects on non-target species, such as when GM plants designed to kill pests also kill non-pests. ${ }^{7}$

For Europe, with its relatively small landmass, the environmental risks are compounded. Deliberate release of GMOs is by definition trans-boundary, as the GMOs interact directly with the environment. This risk of "free migrants" is particularly troubling if Member States are to have different regulatory regimes for GMOs; despite any legal barriers an individual Member State may put up to the trans-border movement of GMOs, the risk still remains that GM crops or seeds could cross national boarders of their own free will. In essence, the choice of one Member State to permit GMOs into the market could be a choice for all. The fact that GMOs may not be easily removed from the environment once they are introduced makes the GMO question a unique lens through

SCIENTISTS' Working GROUP ON BIOSAFETY, MANUAL FOR ASSESSING ECOLOGICAL AND HuMAN HeALTH EFFECTS OF GENETICALLY ENGINEERED ORGANISMS (1998)).

${ }^{3} I d$. at 351-2. The most famous example of GMO poisoning was when Kraft, a large manufacturer of food products, inadvertently mixed Starlink corn, which was engineered to produce a bacterial toxin poisonous to insects, with corn used in the production of food for human consumption. See Julie Teel, Rapporteur's Summary of the Deliberative Forum: Have NGOs Distorted or Illuminated the Benefits and Hazards of Genetically Modified Organisms?, 13 COLO. J. InT'L ENV'TL L. \& POL’Y 137, 141 (2002).

${ }^{4}$ UNDP, HUMAN DEVELOPMENT REPORT 2001: MAKING NEW TECHNOLOGIES WORK FOR HUMAN DEVELOPMENT 67 (2001). Recently, in Europe, Syngenta, a Swiss biotech company based in Basel has admitted to mixing up batches of its Bt 10 and Bt 11 corn, accidentally releasing Bt 10 corn into the European market before it could be approved. Tom Wright, U.S. Fines Swiss Company Over Sale of Altered Seed, N.Y. TIMES, April 9, 2005, at B2.

${ }^{5}$ Jared Babula, Transgenic Crops: A Modern Trojan Horse, 3 J.L. \& Soc. Challenges 127, 131 (1999).

${ }^{6}$ See HuMAN DEVELOPMENT REPORT, supra note 4 at 131.

${ }^{7} \mathrm{Id}$. 
which to view issues of European integration; particularly integration of the regulatory state.

Based on the current state of Community law and the political sentiment surrounding GMOs, this paper argues that the best approach to regulating the import and export of GMOs into the Community and between Member States is by what Francesca Bignami and others have called conditions of anarchy and what I will call for the purposes of this Paper "regulatory anarchy." ${ }^{8}$ This system sits in opposition to a hierarchical regulatory approach which may be associated with traditional neofunctionalist theories of Community integration. Applied in the context of GMOs, regulatory anarchy envisions integration not coming solely from Community rules conceived by the Commission, but by Member State negotiated rules accomplished at the level of regulatory civil servants negotiating among each other. Greater centralization will occur in the regulation of GMOs, particularly because as Bignami points out, the risk of defection in this area by an individual regulatory body imposes very high costs on other national regulators, to the point where they are willing to relinquish some of their own enforcement authority for assurances against collective action problems. ${ }^{9}$

Part II gives a brief overview of the European GMO regulations as they currently exist, focusing particularly on Directive 2001/18/EC (Deliberate Release Directive), which determines the procedure by which the risks of GMOs are assessed and also outlines the approval process Member States must implement for release of GMOs into the European market. Many Member States, in response to popular opinion, have

\footnotetext{
${ }^{8}$ Francesca Bignami, The Challenge of Cooperative Regulatory Relations after Enlargement, in LAW AND GOVERNANCE IN AN ENLARGED EUROPEAN UnION, ESSAYS IN EUROPEAN LAW 97, 101 (George A.

Bermann \& Katharina Pistor eds., 2004).

${ }^{9} \mathrm{Id}$. at 101 .
} 
suspended the consideration of applications for GMO release in their territory, bringing the regulatory system to a standstill. This section highlights some of the problems inherent in the current regime, particularly the way science and policy are considered in asymmetrical ways at different stages of the approval process. This creates a disproportionately large burden on Member States seeking to protect their domestic markets from GMOs.

The problem of diminished regulatory choices for "third-party" Member States is addressed in Part III. If a third-party Member State does not approve of the release of a specific GMO into the territory of another Member State, it may object at the Community stage of the approval process. Due to the unbalanced application of scientific and policy considerations and the comitology procedure, however, objections are rarely effective. Part III also examines another option for third-party Member States - outright bans on GMOs - and determines that based on current case law, the European Court of Justice (ECJ) will not look kindly on attempts to justify violations of Article 28 of the Treaty Establishing the European Community ${ }^{10}$ (EC Treaty) based on human health or environmental considerations, particularly where harmonization in the area already exists.

Part IV builds on the findings of Part III, asking the question of whether the current complex architecture best serves the needs of individual Member States, as well as the Community as a whole. This is necessarily a theoretical exercise that abstracts the relationships observed in the earlier part of this paper to outline the underlying tensions that inform the current system's organization. Due to the gridlock caused by recalcitrant

\footnotetext{
${ }^{10}$ Treaty Establishing the European Community, Nov. 10, 1997, O.J. (C 340) 3 (1997).
} 
Member States, the GMO regime may be more effectively and efficiently handled by a system that employs regulatory anarchy; whereby twenty-five interested parties are initially brought to the table to approve a release (rather than one Member State), leaving less opportunities for regulatory capture by one Member State and still leaving room for Community supervision. Part IV uses the example of the Regulation on Food and Feed to illustrate how the system is already moving in this more effective direction.

\section{The Deliberate Release Approval Process - An Amalgam of Competences}

The EU currently regulates the release of GMOs via a set of directives and regulations $^{11}$, of which Directive 2001/18/EC (Deliberate Release Directive) forms the backbone. ${ }^{12}$ The Deliberate Release Directive was adopted pursuant to Article 95 of the EC Treaty, which empowers the Council to adopt measures having as their objective the establishment and functioning of the internal market. ${ }^{13}$ The directive, necessarily then, has as its primary function the regulation of the internal market. The directive does identify a range of objectives that may be pursued in the GMO approval process: the directive imposes a duty on Member States to take "all appropriate measures" to avoid

\footnotetext{
${ }^{11}$ For a timely list of EU legislation governing GMOs, see SHAFFER \& POLLACK, surpa note 1 at Box. 2. The 1957 Treaty of Rome, which established the European Community, made no explicit mention of food regulation; nevertheless the EU has developed a de facto food policy as instruments designed to regulate agriculture and establish an internal food market have "spilled over" into regulating the characteristics of food. Mark A. Pollack \& Gregory C. Shaffer, The Challenge of Food Safety in Transatlantic Relations, in TRANSATLANTIC GOVERNANCE IN THE GLOBAL ECONOMY 157 (2001). This is very similar to the United States' reliance on the Commerce Clause to regulate food safety in the twentieth century. Id.

${ }^{12}$ Council Directive 2001/18/EC on the Deliberate Release into the Environment of Genetically Modified Organisms and Repealing Council Directive 90/220/EEC, 2001 OJ (L 106) [hereinafter Deliberate Release Directive]. The Deliberate Release Directive repealed Directive 90/220/EEC which also regulated the release of GMOs; the major difference between the two directives is that the Deliberate Release Directive requires a Member State to consult with scientific authorities when making the determination whether or not to permit a release onto the market. Aaron A. Ostrovsky, Note, The New Codex Alimentarius Commission Standards for Food Created with Modern Biotechnology: Implications for the EC GMO Framework's Compliance with the SPS Agreement, 25 MiCH. J. INT'L L. 813, 816 (2004). For an updated list of EU legislation governing GMOs, see SHAFFER \& POLLACK, supra note 1 at Box. 2.

${ }^{13}$ Case C-6/99, Association Greenpeace France v. Ministere de l'Agriculture et de la Peche, Opinion of Advocate General Mischo, 2000 E.C.R. I-1651, at para. 66 [hereinafter Greenpeace France AG Opinion].
} 
"adverse effects on human health and the environment."14 Therefore, while the Deliberate Release Directive is clearly designed to regulate the internal market, it has an environmental component as well.

\section{A. Mechanics of the Deliberate Release Directive}

The approval process for GMOs outlined in the Deliberate Release Directive involves a complex amalgam of Member State and Community actions. The directive sets up a unique procedure that involves both a decentralized Member State stage favoring national authorities, based on a model used in environmental regulation ${ }^{15}$, and a centralized Community stage, similar to that which is used in marketing certain medicines. ${ }^{16}$ Regulatory power does not accrue exclusively to any one level of governance but is shared across different levels. ${ }^{17}$

Before a manufacturer or importer can place a GMO on the market of a Member State, it must first submit a notification dossier to the "competent authority" of the Member State. ${ }^{18}$ The Member State's competent authority must carry out a risk assessment of the product; particularly noting the environmental risk assessment (ERA) submitted by the applicant, recommendations for safe use and handling of the product, and whether the product represents a risk to human health or the environment. ${ }^{19}$ At this stage of the procedure, the scientific analysis of the GMO, and the determination of the

\footnotetext{
${ }^{14}$ Deliberate Release Directive, supra note 12 at art. 4(1).

${ }^{15}$ See, e.g., Council Directive 75/442 relating to waste, 1975 OJ (L 194), as amended by Council Directive 91/156, 1991 OJ (L 78) (imposing an obligation to obtain a prior authorization for any waste disposal or waste treatment operations).

${ }^{16}$ Estelle Brosset, The Prior Authorization Procedure Adopted for the Deliberate Release into the Environment of Genetically Modified Organisms: the Complexities of Balancing Community and National Competences, 10 EUR. L. J. 555, 558 (2004); Greenpeace France AG Opinion, supra note 13 at para. 69.

17 JOANNE SCOTt, EUROPEAN REGULATION OF GMOS: THINKING ABOUT “JUDICIAL REVIEW" IN THE WTO 2 (Jean Monnett Working Paper 04/04, 2004).

${ }_{18}$ Deliberate Release Directive, supra note 12 at art. 13.

${ }^{19} \mathrm{Id}$. at art. 13(1)(2). See also, Brosset, supra note 16 at 565.
} 
quality of the ERA is within the competence of the single Member State. The competent authority may either reject the proposed release or forward the dossier the Commission with a favorable opinion. ${ }^{20}$ At this stage of the procedure, the competent authority may exercise a large degree of discretion in determining the acceptable level of risk, particularly in situations where scientific evidence is inconclusive. ${ }^{21}$ The Member State's regulatory power is concentrated at this initial approval stage; the discretion granted to the Member State is essentially a veto power that may serve to bring the entire approval process to a halt.

After receiving notification of the intent to release a GMO, the Member State must submit an assessment report to the Commission, stating whether or not the GMO in question should be placed on the market. ${ }^{22}$ The Commission must notify the competent authorities of all other Member States of the potential release and forward them the dossier. $^{23}$ At this stage of the process, control moves from the discreet Member State stage to the collective Member State stage; if any Member State objects to the release, the Commission must form a committee composed of Member State representatives and chaired by a Commission representative. ${ }^{24}$ This proceeds according to the standard comitology procedure used in the Community for a regulatory procedure ${ }^{25}$, governed by

\footnotetext{
${ }^{20}$ Deliberate Release Directive, supra note 12 at art. 14(3).

${ }^{21}$ Brosset, supra note 16 at 558.

22 Deliberate Release Directive, supra note 12 at art. 14(2).

${ }^{23} \mathrm{Id}$. at art. $15(1)$.

${ }^{24} I d$. at art. 30.

${ }^{25}$ See Europa website, Glossary, Comitology, at http://europa.eu.int/scadplus/leg/en/cig/g4000c.htm. For a description of the comitology procedure, see FRANCESCA BIGNAMI, THE ADMINISTRATIVE STATE IN A SEPARATION OF POWERS CONSTITUTION: LESSONS FOR EUROPEAN COMMUNITY RULEMAKING FROM THE United States (Jean Monnet Working Paper No. 5/99, 1999), at www.jeanmonnetprogram.org/papers/99/990502.html.
} 
the Comitology Decision. ${ }^{26}$ After an objection and the formation of a committee, both the Member States and the Community have input into the decision making process. The committee must vote by a qualified majority as laid out in Article 205(2) of the EC Treaty on whether to approve the release. ${ }^{27}$ If the committee cannot come to a decision, control of the approval process moves solely to the Community level; the Commission must submit the question to the Council which must vote by qualified majority on whether to approve the release. ${ }^{28}$ If the Council fails to make a decision, the Commission must permit the release. ${ }^{29}$ At this point, the Member State is required to consent in writing to the release. ${ }^{30}$ The Deliberate Release Directive clearly states in Article 18 that, "where a favourable decision has been taken, the [Member State] which prepared the report shall give consent in writing to the placing on the market [of the GMO in question]." ${ }^{31}$

In one of the few cases dealing specifically with GMOs, Greenpeace France v. Ministere de l'Agriculture ${ }^{32}$, the ECJ addressed specifically how much discretion a Member State has at this final point in the approval process: the answer, virtually none. The function of the Member State is merely to "ratify" the decision of the Commission. ${ }^{33}$ In 2000, France had received a request to place genetically modified maize on the French

\footnotetext{
${ }^{26}$ Council Decision 1999/468/EC, [1999] O.J. (L 184) 23, repealing Council Decision 87/373/EEC, [1987] O.J. (L 197) 33.

${ }^{27}$ Council Decision 1999/468/EC laying down the procedures for the exercise of implementing powers conferred on the Commission, 1999 OJ (L 184), at art. 5(2). It is important to point out that the chairman of the committee, who is a representative of the Commission, does not vote.

${ }^{28} \mathrm{Id}$. at art. 5(4),(6).

${ }^{29} \mathrm{Id}$. at art. 5(6).

${ }^{30}$ Deliberate Release Directive, supra note 12 at art. 18(2).

${ }^{31} I d$. (emphasis added).

${ }^{32}$ Case C-6/99, Association Greenpeace France v. Ministere de l'Agriculture et de la Pêche, 2000 E.C.R. I1651, at para. 24 [hereinafter Greenpeace France].

${ }^{33}$ Brosset, supra note 16 at 565
} 
market. ${ }^{34}$ After forwarding the dossier to the Commission with a favorable opinion, as required by Article 12 of Directive 90/220/EEC (the predecessor to the Deliberate Release Directive) $)^{35}$, other Member States objected to the release. ${ }^{36}$ The Commission submitted a favorable proposal for a decision to the committee as required by Article 21 of the directive. ${ }^{37}$ After the committee failed to make a decision, the Commission forwarded the dossier to the Council which also failed to make a decision. ${ }^{38}$ The Commission then decided that "the French authorities shall give consent to the placing on the market" of the GM maize. ${ }^{39}$ France's Minister of Agriculture and Fisheries then adopted a decree authorizing the placement as well. ${ }^{40}$

Greenpeace France, along with four other parties, brought a suit in French court (Counseil d'Etat) seeking to annul the decree. The Counseil d'Etat referred the question of Member State discretion to the ECJ. The court held that there was no ambivalence in the wording of Article 13(4) of Directive 90/220/EEC (now Article 18 of the Deliberate Release Directive) and that Member States were clearly required to give consent after Commission approval. ${ }^{41}$ The ECJ further added that the Community phase of the decision making process comes into play only after a Member State has "had the opportunity to fully exercise [its] own powers to asses the risks which the release of

\footnotetext{
${ }^{34}$ LUdWig KRÄMER, CASEBooK ON EU ENVIRONMENTAL LAW 234 (2002).

${ }^{35}$ This case interpreted Directive 90/220; however the similarities between Directive 90/220 and the Deliberate Release Directive on the points the ECJ considers makes the case applicable to the present discussion of the Deliberate Release Directive as well.

${ }^{36}$ KRÄMER, supra note 34 at 234.

${ }^{37} \mathrm{Id}$.

${ }^{38} I d$.

${ }^{39}$ Id (quoting Decision 97/98, Commission, 1997 OJ (L31/69)).

${ }^{40} I d$.

${ }^{41}$ Greenpeace France, supra note 32 at paras. 28,29.
} 
products containing GMOs entails for human health and the environment."42 The court interpreted the division of power between the Member States and the Community as hierarchical rather than collaborative; the Member State is first and foremost the decision making body and is free to forward its own normative regulatory agenda before the Community institutions or other Member States can get involved.

Advocate General Mischo, in his preceding opinion, had interpreted the wording of the directive as the court did, but added another layer of reasoning. Mischo pointed out that after one Member State sends a favorable opinion to the Commission, other Member States are notified:

If the first Member State could freely decide, entirely on its own, not to give its consent in writing [after the approval by the Community], the second Member State could then initiate a fresh procedure leading, in the absence of any new factors, to another favourable decision which would then be binding on the first Member State. In that case, the first Member State would not longer be able to oppose the marketing of the product in its territory. ${ }^{43}$

Based on this reasoning, it becomes clear that the power division within the Deliberate Release Directive is not hierarchical in the sense of $a$ Member State decision having priority over Community decisions. Rather, the power structure is better described as all Member State decisions having priority over Community decisions. What this leads to is a situation where the more strict regulatory preferences of some Member States are undermined by the less strict regulatory preferences of perhaps just one.

\section{B. Science, Policy, and the Regulatory Blockade}

The desire for harmonization and the free movement of goods on the part of Community institutions necessitated the centralization present in the approval system, primarily to prevent wildly different interpretations among the Member States of the risks

\footnotetext{
${ }^{42} I d$. at para. 39.

${ }^{43}$ Greenpeace France AG Opinion, supra note 13 at para. 45.
} 
that GMOs present. ${ }^{44}$ The political sensitivity of GMOs, however, required that Member State regulators have significant input into the determination of risks of biotechnology, as well as participation in the final approval decision. ${ }^{45}$ The complexity of this procedure concocted to serve dual needs of the Community and Member States has created an administrative morass with the outcome being an approval process obstructed by unresolved conflicts - only one GMO has been placed on the market since the Deliberate Release Directive was adopted, Monsanto's "Roundup Ready” maize in Spain. ${ }^{46}$

The reasons for the blockage vary at the Member State stage from some Member States not allowing release in the face of negative public opinion, to certain Member States using this procedure to put pressure on Community institutions for political gain. ${ }^{47}$ Because approval at the Community stage relies on a qualified majority vote either in a regulatory committee or the Council, consistent dissent by some Member States has led to an inability to come to decisions either approving or rejecting release. ${ }^{48}$ This in turn has led to the Commission taking ultimate responsibility for the decision, as provided for under comitology procedures, further delegitimizing the system. ${ }^{49}$

Part of the problem may be attributed to the divergence between science and policy at the different stages of the approval process. The major difference between the

\footnotetext{
${ }^{44} I d$. at 559.

${ }^{45} I d$.

${ }^{46}$ See Biotechnology \& GMOs information website, at http://gmoinfo.jrc.it/gmc browse authorized.asp. See also, Clive James, Preview: Global StATUs of COMMERCIALIZED BIOTECH/GM CROPS: 20044 (ISAAA 2004) (stating that Spain has achieved the classification of "biotech mega-country," planting more than 50,000 hectares of GM crops), at http://www.isaaa.org/kc/CBTNews/press_release/briefs32/ESummary/Executive\%20Summary\%20(Englis h).pdf.

${ }^{47}$ Brosset, supra note 16 at 567.

${ }^{48}$ EUR. COM. Doc., Communication to the Commission for an orientation debate on Genetically Modified Organisms (Jan. 28, 2004)[hereinafter Communication], at http://europa.eu.int/comm/agriculture/envir/gmo/commdebate_en.pdf. ${ }^{49}$ Id.
} 
Deliberate Release Directive and the legislation it amended, Directive 90/220/EEC, is that the Deliberate Release Directive requires that a "Scientific Committee" be consulted if an objection to release is raised, either at the Member State stage or at the Community stage of the approval process. ${ }^{50}$ Implicit in this requirement is the notion that risk assessment be justified in whole or in part on scientific findings of risk; the legitimacy of the intervention then is not founded on scientific certainty of safety, but rather motivated by the uncertainty of the existence and scope of potential risk. ${ }^{51}$ Science serves only to provide the means by which Member States or the Commission may make a meaningful objection to release; a prudential approach that goes to the assessment of risk but not the management of risk. ${ }^{52}$

At either stage of the approval process, however, both risk assessment and risk management are required; public policy considerations play a large part in devising risk management options. The Deliberate Release Directive requires that Member States act "in accordance with the precautionary principle;",53 a requirement that addresses itself to the risk management stage of the procedure, rather than the risk assessment stage. ${ }^{54}$ The precautionary principle is applied when there is little scientific certainty in risk assessment; the regulator must "act before knowing." 55 Judging what is an acceptable level of risk in the face of scientific uncertainty is an eminently political determination;

\footnotetext{
${ }^{50}$ Deliberate Release Directive, supra note 12 at art. 28(1). See also, Ostrovsky, supra note 12 at 816.

${ }^{51}$ Zeynep Kivilcim Forsman, Community Regulation of Genetically Modified Organisms: a Difficult Relationship Between Law and Science, 10 EUR. L.J. 580, 584 (2004).

${ }^{52} I d$.

${ }^{53}$ Deliberate Release Directive, supra note 12 at annex II, $\S$ A, B, pmbl..

${ }^{54}$ Communication from the Commission on the Precautionary Principle, $\operatorname{COM}(2000) 1$ at 3,8 (2000)[hereinafter COM(2000)]. Analysis of risk can be broken down into: risk assessment, risk management, and risk communication. The precautionary principle is particularly relevant to the management of risk. Id.

${ }^{55}$ Forsman, supra note 51 at 582.
} 
requiring in some instances non-action, or at least not introducing binding legislation. ${ }^{56}$

In this light, it makes sense that in the face of politically costly decisions to allow GMOs to enter, many Member States have relied on a precautionary approach at the initial stages of the approval process to make a political decision to not allow GMOs to be released. This tendency towards procedural blockage at the initial stage of the process is underscored by the fact that, at least in terms of GM crops, Member States have not been willing to accept the ERAs of other Member States at the Community stage, even if a common basis for such risks is foreseen in the Deliberate Release Directive. ${ }^{57}$ Further, if some Member States are given to managing risks more loosely as a political decision, there is the potential for forum shopping by the regulated industry - again leading to a situation where the system is held hostage by the most pro-GMO Member States.

\section{Member State Options for Regulating GMOs Beyond the Approval Process}

As shown above, the normative regulatory preferences of an individual Member State may play a substantial role in the GMO approval process if that Member State happens to be the one in which the initial release will occur. What about the Member States that do not receive the initial application? Because of the Community's comitology procedure, a specific GMO may still be approved for release despite the objections of one or more Member States after the initial Member State's approval. In addition, based on ECJ case law on free movement of goods, is there a possibility for individual Member States to refuse to admit GMOs into their market even after a release

\footnotetext{
${ }^{56} \mathrm{COM}(2000) 1$ at 4.

${ }^{57}$ Report from the Commission to the Council and the European Parliament on the experience of member states with GMOs placed on the market under Directive 2001/18/EC and incorporating a specific report on the operation of parts B and C of the Directive, COM/2004/0575 final at point 6 (2004).
} 
has been approved on a Community level? Member State autonomy is ultimately preserved even after the final decision, but in limited, and uncertain terms: it may flow from the safeguard clause in Article 23 of the Deliberate Release Directive. ${ }^{58}$ This source of autonomy, however, has been curtailed in recent legal decisions, and in more specialized GMO legislation. ${ }^{59}$

This section address the second two of three areas where Member States can give input into the approval process: as a "third-party" objector at the Community stage, and post-approval by banning individual GMOs on a national level. Neither of these two avenues has been successful for Member States. Objections at the Community stage of the approval process have been thwarted by comitology procedures and questionable scientific determinations of risk. At the national level, Member States must contend with current ECJ caselaw and Commission decisions, both in regard to the ECJ's caselaw regarding justifications for violations of Article 28 of the Treaty as well as the application of Article 23 of the Deliberate Release Directive, a safeguard clause which applies when "new or additional information" regarding a specific release is discovered. ${ }^{60}$

The ECJ's primary role in Community regulation is to ensure that the rules are applied reasonably evenly. ${ }^{61}$ Under the existing Cassis de Dijon doctrine, nondiscriminatory trade restrictive measures must be balanced against court determined "legitimate ends," as understood in the U.S. parlance. Where Community harmonizing

\footnotetext{
${ }^{58}$ SCOTT, supra note 17 at 3.

${ }^{59}$ See, e.g., Commission Decision 2003/653 OJ [2003] L230/34 in which the Commission denied Austria recourse to art. 95 when it tried to ban GMOs in Northern Austria. Similarly, Member State autonomy is more limited in the 2003 GM Food and Feed Regime that it was in the Deliberate Release Directive. See Regulation 1829/2003 on genetically modified food and feed OJ [2003] L/268/1 [hereinafter Food and Feed Regulation].

${ }^{60}$ Deliberate Release Directive, supra note 12 at art. 23.

${ }^{61}$ SHAFFER \& POLLACK, supra note 11 at 46 (quoting POLICY-MAKING IN THE EUROPEAN UNION (Helen Wallace, et al. eds. 2005)).
} 
measures exist in the area the Member State seeks to create regulations, the bar becomes much higher for Member States to justify more restrictive regulations. This in turn results in a diminishing of avenues for Member States to assert a non-GMO preference and still be in compliance with ECJ decisions.

\section{A. The Questionable Effectiveness of Member State Objections at the Community Level of the Approval Process}

As discussed above, the Deliberate Release Directive requires that a Member

State, upon receiving a notification of release, forward that notification on to the competent authorities of the other Member States. ${ }^{62}$ At this stage of the approval process, other "third-party" Member States may object to the release. While in the abstract, this "input stage" of the process would seem to indicate a more integrated approach to approval, the actual substantive impact of third-party Member State objections on the approval process is mitigated by both the comitology procedure and the reliance on scientific evidence to show risk.

The Deliberate Release Directive provides for adherence to the Community's standard comitology procedure; the Commission may only make a decision if the committee of representatives of Member States and the Council both fail to come to a decision by qualified majority. ${ }^{63}$ This would imply that the Commission's discretion is subsidiary to the Member States' and the Council ${ }^{64}$; in actuality however, a failure to reach a qualified majority at either the committee or Council stages is not uncommon. ${ }^{65}$

\footnotetext{
${ }^{62}$ Deliberate Release Directive, supra note 12 at art. 13(1).

${ }^{63} I d$. at art. 18-30(2).

${ }^{64}$ See Brosset, supra note 16 at 564.

${ }^{65}$ See Press Release, Lim Li Ching, Institute of Science in Society, Europe Still Resisting GMOs (2004) (stating that qualified majority failed to be reached at the committee or Council level at least seven times in 2004), at http://www.i-sis.org.uk; Communication, supra note 48 at 2.2.
} 
Therefore, despite third-party Member States' objections, the comitology procedure allows the Commission to approve release in many instances. ${ }^{66}$

In addition to comitology, non-standardized scientific assessments of risk at various stages of the approval process also hamper the efficacy of third-party Member State objections. Under the original Directive 90/220/EEC, every single application for release into the common market met objections from at least one third-party Member State; the objections usually centered around adverse "secondary effects" of the product such as the potential for the development of super-weeds or insects resistant to insecticide. $^{67}$ Two examples involved Ciba-Geigy and Plant Genetics Systems' applications to release herbicide-tolerant GMOs in France and the UK respectively. ${ }^{68}$ In both cases, the dispute was over the GMOs' secondary effects: proponents of the release urged that Directive 90/220/EEC only required that direct ecological effects of the GMO be mitigated; ${ }^{69}$ opponents focused on the broader language of the directive, which requires measures be taken to avoid "adverse effects on human health and the environment."70 In both cases the Commission granted approval for release. In the UK case, the Commission agreed with the UK that "any spread or transfer of the herbicide-

\footnotetext{
${ }^{66}$ For a general critique of the comitology procedure as it has been applied in the environmental sector in the EU, see Christophe Demke, Comitology in the Environmental Sector, in DELEGATED LEGISLATION AND THE ROLE OF COMMITTEes IN THE EC 287 (Mads Andenas \& Alexander Türk eds., 2000).

${ }^{67}$ LES LEVIDOW, SusAN CARR \& DAVID WIELD, ENVIRONMENTAL RISK DISHARMONIES OF EUROPEAN BIOTECHNOLOGY REGULATION (Biosafety Reviews 2000), at http://binas.unido.org/binas/show.php?id=1\&type=html\&table=book_sources\&dir=reviews.

${ }^{68} I d$. In respect to this dispute, the language of Directive 90/220/EEC and the Directive 2001/18/EC are identical.

${ }^{69} I d$.

${ }^{70} I d$. The requirement for protection of human health and the environment appears prominently in both directive 90/220/EEC and 2001/18/EC.
} 
tolerant gene could be controlled by using existing management strategies." ${ }^{, 71}$ There was some ambiguity, however, in the UK government's assessment of risk; one member of the UK advisory committee noted a "gray area between safety and agricultural strategy," alluding to the fact that regulators may assess risk partially based on economic advantages to approving the release. ${ }^{72}$

Similarly, in the French case, the France approved the release but recommended post-approval monitoring of the GMO for five years, stating that while it perceived "no uncertainties about an identified or potential risk," there were "unknowns about socioeconomic consequences." ${ }^{, 73}$ The Commission approved France's management plan. ${ }^{74}$ In this case, France adopted a plastic understanding of environmental risk: in approving the product, France tolerated a high level of risk; in monitoring the product, however, the tolerance of risk was significantly lowered. This changeable level of acceptable risk makes it easier for the original releasing Member State to allow the release, while still addressing, at least in a formal sense, objecting Member States' concerns through monitoring or labeling regimes. In reality, though, because it is the actual release which is generally objected to (risk assessment), not the system of management (risk management), the objecting Member States' concerns may not actually be wholly considered.

\footnotetext{
${ }^{71}$ Commission decision 96/158/EC of 6 February 1996 concerning the placing on the market of a product consisting of a genetically modified organism, hybrid herbicide-tolerant swede-rape seeds (Brassica napas L. oliefera Mtzq. MS1Bn x RF1Bn), pursuant to Council Directive 90/220/EEC, [1996] OJ 30 (L037).

${ }^{72}$ LEVIDOW, supra note 67.

${ }^{73}$ Id. (citing A. Khan, Evaluation du risqué et dissmemination volotaire d'organismes genetiquement modifies: l'experience francaise, 96 NATURES-SCIENCES-SOCIETES DIALOGUES 144-5 (1996)).

${ }^{74}$ Id. See also, Commission Decision 97/98/EC of 23 January 1997 concerning the placing on the market of genetically modified maize (Zea mays L.) with the combined modification for insecticidal properties conferred by the Bt-endotoxin gene and increased tolerance to the herbicide glufosinate ammonium pursuant to Council Directive 90/220/EEC, [1997] OJ 69 (L031).
} 
In both the French and UK case, the third-party Member States' objections either fell prey to the economic concerns of the original Member State or an amorphous understanding of risk on the part of the original Member State. In either case, however, a third-party Member State objecting to the release would have had to produce scientific evidence of risk so substantial that it would have overcome both public policy economic considerations as well as a contracting and expanding understanding of risk. This high bar placed on the third-party Member State makes objections at the Community stage of the approval process an unreliable means of asserting normative regulatory preferences regarding GMOs.

\section{B. The Possibility for Individual Member State Prohibitions of GMOs Post Approval - Beyond Cassis de Dijon?}

Because the objection provision at the Community stage of the approval process may not yield the desired fruit for third-party Member States, another option may be to impose domestic bans on specific GMOs after they have been approved at the Community stage. Can a third-party Member State still ban GMOs within its own territory without violating the EC Treaty's requirement of free movement of goods?

Article 28 of the EC Treaty prohibits quantitative restrictions on imports and exports and "all measures having equivalent effect,",75 including absolute bans on a product. ${ }^{76}$ Member States, however, may restrict the free movement of goods across their borders if those restrictions are justified on grounds of, inter alia, "public morality, public policy or public security" or "the protection of health and life of humans, animals and

\footnotetext{
${ }^{75}$ EC Treaty, Arts. 28.

${ }^{76}$ See, e.g., Case 34/79, Regina v. Henn \& Darby, 1979 E.C.R. 3795.
} 
plants." Member State restrictions based on Article 30 cannot constitute "a means of arbitrary discrimination or a disguised restriction on trade between Member States."78 While the definition of what constitutes a quantitative restriction is broad ${ }^{79}$, the ECJ has narrowed it. In Keck, the ECJ held that "selling arrangements" that were generally applicable and affected the both domestic and foreign traders in the same manner "in law and in fact" fall completely outside the scope of Article 28 and therefore are not reviewable by the court. ${ }^{80}$ Selling arrangements include regulations that deal with the way a product is sold but do not deal with actual characteristics of the product itself. ${ }^{81}$ Because a ban on GMOs would by nature deal with the characteristics of the product itself and not the way it is sold, despite the generally applicable and non-discriminatory nature of a ban, it would most likely fall within the scope of Article 28.

The boundaries of legitimate regulation under Article 28 and limits of Article 30 exceptions are laid out in Cassis de Dijon. Cassis de Dijon ${ }^{82}$ dealt with a German law which required fruity alcoholic beverages to have a threshold level of alcohol. The ECJ found that, in light of the lack of harmonization in this area, because alcoholic beverages

\footnotetext{
${ }^{77}$ EC Treaty at Art. 30.

${ }^{78}$ Id. See Case 121/85, Congate v. HM Customs and Excise, 1986 E.C.R. 1007 (holding that national legislation cannot limit the import of pornography if the legislation does not also prohibit domestic pornography).

${ }^{79}$ Indeed, in the seminal Dassonville case, the ECJ determined that "[a]ll trading reules enacted by Member States which are capable of hindering, directly or indirectly, actually or potentially, intra-Community trade are to be considered as measures having an effect equivalent to quantitative restrictions." Case 8/74, Procureur du Roi v. Dassonville, 1974 E.C.R. 837, at para. 5. This definition quickly became unwieldy in its scope and was later narrowed in Cassis de Dijon. See Case 120/78, Rewe-Zentral v.

Bundesmonopolverwaltung fur Branntwein, 1979 E.C.R. 649.

${ }^{80}$ Case C-267 \& 268/91, Keck and Mithouard, 1993 E.C.R. I-6097, at para. 15-6.

${ }^{81}$ See, e.g, Case C-391/92, Commission v. Greece, 1995 E.C.R. I-1621 (national law requiring infant formula to be sold only in pharmacies is a selling arrangement); Case C-412/93, Societe d'Importation Edouard Leclerc-Siplec v. TFI Publicite, 1995 E.C.R. 1-179 (national law banning some advertising on television a selling arrangement). But see, Case C-405/98, Konsumentombusmannen v. Gourmet International Products, 2001 E.C.R. I-1795 (law banning all forms of advertising for alcohol violates art. 28 because it is de facto discriminatory).

${ }^{82}$ Case $120 / 78$, at para. 8 .
} 
had been lawfully produced and marketed in one Member State, there was no valid reason why they should not be introduced into any other Member State. ${ }^{83}$ This presumption in favor of marketing has been referred to as the mutual recognition principle: if one Member State allows the product to be marketed, all other Member States should have confidence in the first State's judgment and allow the product in their own territory as well. ${ }^{84}$ The adoption of the mutual recognition principle in Cassis de Dijon points to an inherent belief by the ECJ that most regulatory measures hinder intraEuropean trade without any compensating welfare-enhancing effect. ${ }^{85}$ This is based on assumptions about protectionist motives on the part of the Member States. ${ }^{86}$ The German law in Cassis de Dijon was clearly discriminatory and this informed a great deal of the ECJ's reluctance to accept Germany's reason for the law. ${ }^{87}$

The prohibition on trade-distorting measures under Article 28 is not absolute. The ECJ acknowledged that obstacles to free movement caused by differences in regulation are acceptable so long as they are found necessary to satisfy "mandatory requirements," such as "the effectiveness of fiscal supervision, the protection of public health, the fairness of commercial transactions and the defense of the consumer." ${ }^{88}$ This list loosely tracks the exceptions to Article 28 prohibitions listed in Article 30 of the EC Treaty, however Cassis de Dijon has been read as an expansion of Article 30 as well. By requiring that protective measures be "necessary" to satisfy social needs, the ECJ

\footnotetext{
${ }^{83} \mathrm{Id}$. at para. 14.

${ }^{84}$ CASES ANd Materials on EuRopean Union LaW 511 (George A. Bermann, et. al eds., 2002).

${ }^{85}$ Bignami, supra note 8 at 132.

${ }^{86} \mathrm{Id}$. at 133 .

${ }^{87}$ Case $120 / 78$, at paras. 12-14.

${ }^{88} \mathrm{Id}$. at para. 9. In Keck, the ECJ replaced the term "mandatory requirement" with "public-interest objective", thereby clarifying that Member States can violate Article 28 for normative regulatory reasons. See Case C-267 \& 268/91, at para. 15.
} 
introduced a proportionality test which it solidified in later in Criminal Proceedings Against Sandoz, where it stated: "[T] he principle of proportionality which underlies the last sentence of Article [30]...requires that the power of the Member State to prohibit imports of the products in question from other Member States should be restricted to what is necessary to attain the legitimate aim of protecting health." ${ }^{\prime 89}$

If a Member State were to institute a ban on GMOs, would it be permissible under the exceptions outlined in Cassis de Dijon? A measure banning GMOs would not favor a domestic industry over foreign counterparts and so the ECJ would be more likely to do a genuine balancing of the interests of the Member State (protecting the consumer, environment, etc.) and the Community (free movement of goods) to assess proportionality. ${ }^{90}$ It is important to point out, however, that Cassis de Dijon and subsequent cases dealt with Member State regulations in areas that had not yet been harmonized by Community law. This is not the case with risk assessment for GMOs, where the Deliberate Release Directive does the substantive work. Therefore, despite the fact that a GMO ban would be non-discriminatory, the court would not apply a genuine balancing test where the Community has clearly made an effort towards standardization. $^{91}$ The Member State would have to find relief within the Community measures.

\footnotetext{
${ }^{89}$ Case 174/82, Criminal Proceedings Against Sandoz, 1983 E.C.R. 2445 at para. 18. See, also, Case 788/79, Criminal proceedings against Gilli, 1980 E.C.R. 2071; Bermann, et. al, supra note 84 at 519. ${ }^{90}$ LAURENCE W. GORMLEY, PROHIBITING RESTRICTIONS ON TRADE WITHIN THE EEC 71 (1985)(describing the "rule of reason" outlined in Dassonville as a recognition by the Court, on essentially equitable grounds, that certain interests or values are deserving of judicial protection at the Community level pending the intervention of the Community legislator).

${ }^{91}$ See, e.g., Case 190/87, Oberkreisdirektor des Kreises Borken v. Handelsonderneming Moormann BV, 1988 E.C.R. I-4689 at para.10 (holding that where Community directives provide for the harmonization of the measures necessary to ensure the protection of animal and human health and establish Community procedures to check that they are observed, recourse to Article 36 is no longer justified and the appropriate
} 
Within the confines of the Community law, the Deliberate Release Directive provides for a safeguard clause in Article 23, but requires that any provisional safeguard actions that a Member State takes be based on "new or additional information" which was not considered in the original approval process. ${ }^{92}$ For a third-party Member State whose initial objection was not successful, this procedure is problematic. It is unlikely that the third-party Member State would have any "additional" information beyond what it submitted in its objection in the initial approval process which means the Member State would have to wait for "new" information to become available. ${ }^{93}$ This new information, however, could be the actual damage the GMO does to the Member State's environment, in which case the requirement starts to look unreasonable. The Member State could resort to the precautionary principle, however the ECJ has held that for a Member State to rely on the precautionary principle in safeguard actions, the risk must still be scientifically verified. ${ }^{94}$

Harmonization of risk assessment may not completely rule out a genuine balancing by the court. In Campus Oil, the ECJ held, post-Cassis de Dijon, that even in the presence of Community harmonization in a certain area, Member States may still act to protect themselves: Community harmonization does not give a Member State "unconditional assurance" of protection, and Member States may institute "complementary measures" where protection is not "sufficiently guaranteed by the

checks must be carried out and protective measures adopted within the framework outlined by the harmonizing directive). See also Case 5/77, Tedeschi v Denkavit, 1977 E.C.R. I-1555; Case 148/78, Ratti, 1979 E.C.R. I-1629; Case 251/78, Denkavit v. Minister fur Ernahung, 1979 E.C.R. I-3369.

92 Deliberate Release Directive, supra note 12 at art. 23(1).

${ }^{93}$ Indeed, Brosset points out that new information is generally understood to be information gained after the grant of authorization. Brosset, supra note 16 at 575.

${ }^{94}$ Case 236/01, Monsanto Agricoltura Italia SpA v. Presidenza del Consiglio dei Ministri, 2003 E.C.R. I08105 at paras. $106-110$. 
measures taken for that purpose by the Community institution." 95 At this point, it is helpful to note that what is actually harmonized in the Deliberate Release Directive is the procedure for risk assessment, not the actual level of acceptable risk. To put it in the language of U.S. constitutional theory, this is an issue of conflict preemption in terms of the procedural process, but in no way implies field preemption of Member States' normative regulatory requirements. ${ }^{96}$ A Member State, however, must use the harmonized process of risk assessment to demonstrate that the risk is at a level that it deems unacceptable. Due to the substantive and procedural components of this process, a Member State may argue that the level of risk is too high (an un-harmonized area) but will still have to rely on the harmonized risk assessment procedure. Therefore, in applying a balancing test based on Cassis de Dijon, the ECJ would be deferential to the Member State's end (controlling risk at a certain level) but still require adherence to the harmonized Community means of meeting those ends.

Following Campus Oil, if a Member State did not allow any GMOs to enter (essentially setting its risk tolerance level at zero), it may make a case that despite the safeguard procedure within the Community directive, sufficient protection has not been provided for. This case would be far from airtight, however. Unlike a ban on GMOs,

\footnotetext{
${ }^{95}$ Case 73/83, Campus Oil Limited v. Minister for Industry and Energy, 1984 E.C.R. I-02727, at paras. 27, $30-1$.

${ }^{96}$ The concepts of field and conflict preemption originate in U.S. caselaw dealing with the Dormant Commerce Clause. In Glade v. National Solid Waste Management, the Supreme Court said: Absent explicit preemptive language, we have recognized at least two types of implied preemption: field preemption, where the scheme of federal regulation is so pervasive as to make reasonable the inference that Congress left no room for the States to supplement it, and conflict preemption, where compliance with both federal and state regulations is a physical impossibility, or where state law stands as an obstacle to the accomplishment and execution of the full purposes and objectives of Congress.

Gade v. National Solid Waste Management Association, 505 U.S. 88, 98 (1992). See also, ERWIN

Chemerinsky, CONSTITUtional LAW PRINCIPLES AND Policies 376 (2nd ed., 2002).
} 
which would be based presumably on human health and the environment, Ireland's regulation in Campus Oil was upheld based on a public security exception in Article 30 (ex. 36). ${ }^{97}$ The Campus Oil decision has sustained some criticism ${ }^{98}$ and may be limited to the public security exception. The court has not been as generous with exceptions based on human health or the environment in areas where harmonization has already occurred. $^{99}$ It is unlikely the ECJ would look favorably on a reliance on Campus Oil. In terms of environmental justifications, the Commission has already dealt with this issue in the case of Upper Austria's attempt to declare itself a "GMO free zone.", The Commission rejected a request by Upper Austria to institute an all-out ban on GMOs following consultations with the European Food Safety Authority. The Commission pointed out that Austria was aware of the safeguard clause in Article 23 but found it "inappropriate to meet its objective." ${ }^{101}$ The reasons the Commission gave for its decision were, first, that no new scientific evidence had emerged to support a ban (the GMOs had already been approved for release), and second, that Upper Austria had failed to prove the existence of a problem specific to the region that justified such an approach. ${ }^{102}$ The regional parliament justified the ban by claiming the small scale nature of agricultural production in Upper Austria, together with its uniquely high proportion of organic

\footnotetext{
${ }^{97}$ Case 73/83, at para. 35-6.

${ }^{98}$ See GORMLEY, supra note 90 at 137-8(arguing the "apparent approval of unilateral measures in the petroleum sector does little to encourage Community solidarity in the face of common external threats.") ${ }^{99}$ Case 190/87 at para. 10. See also, id. at 58 (discussing application of the "rule of reason" as created in the Dassonville case).

100 See Commission Decision 2003/653, [2003] OJ L230/34; Upper Austria to Appeal Against EC Rejection of GMO Ban, June 11, 2003, EU BUSINESS, available at http://www.euractiv.com/Article?tcmuri=tcm:29111895-16\&type=News. Upper Austria has appealed this decision to the ECJ.

${ }^{101}$ Commission Decision 2003/653, at para. 56.

${ }^{102}$ Upper Austria to Appeal Against EC Rejection of GMO Ban, supra note 100.
} 
farmers, constituted a specific problem for the region. ${ }^{103}$ In this example, while Austria's desire to tolerate zero risk was not challenged substantively, the means by which it illustrated the threat posed by GMOs was, thereby bringing the whole regime into question.

The structure of the Deliberate Release Directive has mitigated a strict reliance on mutual recognition as the sole means of determining safety throughout the Community by requiring other Member States to participate in the approval process. ${ }^{104}$ The basic principle is that a Member State has the opportunity of preventing a GMOs movement through the whole of the Community. ${ }^{105}$ This discretion, of course, relies on the initial receiving Member State sending a favorable opinion to the Commission in the first place and on the objecting Member State being able to assert a compelling case for refusal despite potential favorable opinions by the receiving Member State and the Commission. If a Member State is not the original locus of the application for release, its regulatory powers become substantially minimized under the current Deliberate Release Directive. Despite a procedure for third-party Member State objections, both the comitology procedure and the requirement that objections (even precautionary ones) be substantiated with science limit the Member States' ability to block GMO release into other Member States. In this sense, then, mutual recognition is still significant in that after the GMO has been approved, the doctrine functions to tie the hands of Member States who may have objected to the release from the outset. It becomes even more significant considering that under current ECJ jurisprudence and recent Commission decisions, the

\footnotetext{
${ }^{103} I d$.

${ }^{104}$ Deliberate Release Directive, supra note 12 at art. 11(2).

${ }^{105}$ Brosset, supra note 16 at 563.
} 
likelihood of a Member State successfully defending an absolute ban on an already approved GMO in light of existing Community harmonization is small.

\section{Towards a More Centralized Regulation of Biotechnology?}

As stated above, the Deliberate Release Directive, with its mixing of Member State and Community phases, is designed to serve the dual goals of meaningful Member State involvement in the approval process and establishing a uniform Community level procedure, eliminating national divergences in regulatory policy. ${ }^{106}$ This has not been the case, however, due in some part to legitimate responses of Member States to domestic apprehension about GMOs, but also because of improper, coercive maneuvering by some Member States who have used the regulatory process, and their power within it, to put pressure on Community institutions to act in other spheres of biotechnology regulation. ${ }^{107}$ For instance, the Danish, French, Greek, Italian, and Luxembourg governments had at one point declared that until rules related to monitoring and labeling of GMOs in the Community had been clarified, they would take steps to ensure authorizations for placing on the market would be suspended. ${ }^{108}$ The point is that the collaborative elements of the procedure designed to eliminate regulatory delays have in fact exacerbated them. Part of this problem is due to the fact that, as shown above, meaningful regulatory choices for objecting Member States are severely limited.

While the changes made to the Deliberate Release Directive from the prior Directive 90/220/EEC have tied the hands of Member States to use regulatory blockades

\footnotetext{
${ }^{106}$ See generally Markus Jachtenfuchs \& Beate Kohler-Koch, Governance and Institutional Development, in EUROPEAN INTEGRATION THEORY 103 (Antje Wiener \& Thomas Diez eds., 2004).

${ }^{107}$ Brosset, supra 16 note at 567.

${ }^{108}$ Declaration relating to the proposal for the amendment of Directive 90/220/EEC on genetically modified organisms, EU Council, Environment, Annex, point 1 (1999).
} 
such as safeguard mechanisms ${ }^{109}$, these reforms generally apply to Member State avenues for recourse once approval has already been given and the Member State phase of the approval process has passed. The regulatory blockades, however, have manifested themselves most prominently at the stage of the process where the approval is still almost totally under Member State control. The problem that needs to be addressed then is how to get the regulatory states (and not the political branches) of Member States to communicate in an efficient way.

\section{A. Neo-functionalism Reborn to Regulate Biotechnology?}

One natural response to the current biotechnology conundrum would be to adjust the balance of power in the approval process, such that the Community drives the process from the outset, ensuring uniformity in the application of standards, with the Member States taking up a subsidiary role. This is an adaptation of the classic neo-functionalist approach to integration, best understood in this context as Jean Monnet and Ernst Haas envisioned it: a combination of benevolent technocrats and interest-propelled economic groups who would build Community level coalitions supporting European policy over myopic national interests. ${ }^{110}$ Technocrats would successfully manage concrete Europeanlevel problems, leading to political momentum for more technocratic, supranational supervision, in a continuous feedback loop. ${ }^{111}$ The impetus for this feedback loop in more recent literature has been re-imagined not as success breeding success as the case may be, but rather that, once a rule is chosen, the logic of path dependence drives

\footnotetext{
${ }^{109}$ A major difference between the Safeguard clause in Directive 90/220/EEC and the safeguard clause in art. 23 of Directive 2001/18/EC is that art. 23 requires any new information which a Member State relies on to justify a provisional ban on GMOs must have been acquired after the initial approval. See Deliberate Release Directive, supra note 12 at art. 23(1).

${ }^{110}$ Helen Wallace, European Governance in Turbulent Times, 31 J. COMMON MARK'T STUDIES 293 (1993).

${ }^{111}$ See, Bignami, supra 8 note at 120. See generally JeAn MONNET, MÉMOIRS (1976); Ernst Haas, International Integration: The European and Universal Process, 15 INT’L ORG. 366 (1961).
} 
regulators to choose similar rules, rather than break the mold. ${ }^{112}$ Importantly, the technocracy would be representative of Community goals and values, but not necessarily those of the Member States. ${ }^{113}$ The temptation of this approach, particularly the elite-led gradual integration as specifically endorsed by Monnet, is that the eventual result is peace and prosperity of the system. ${ }^{114}$

On the regulatory level, the idea of mutual recognition, as recognized both by the ECJ in Cassis de Dijon ${ }^{115}$, and by a 1985 Commission White Paper ${ }^{116}$, was not intended to be deregulatory per se, but actually depended on harmonization as a complement to "implement effective Community policies for e.g. the protection of the environment."117 Implicit in this understanding was a deemphasizing of the national regulatory state and a "re-regulation" on the Community level. ${ }^{118}$ A Community level regulatory state, however, was understood as a response to international regulatory failure; Member States

\footnotetext{
${ }^{112}$ Alec Stone Sweet, Neil Fligstein, \& Wayne Sandholtz, The Institutionalization of European Space, in THE InSTITUTIONALIZATION OF EUROPE 18 (Alec Stone Sweet et al. eds., 2001)(“When an institutional or organizational solution to a particular problem emerges and stabilizes into accepted rules and procedures, it will shape subsequent expectation, interactions, and institutional innovation.")

${ }^{113}$ Paul Craig, The Nature of Community: Integration, Democracy, and Legitimacy, in THE Evolution of EU LAW 1, 7 (Paul Craig \& Gráinne de Burca eds., 1999). Craig points out that for Jean Monnet, democracy, or democratic legitimacy was secondary to peace and prosperity partially because Monnet felt that the best way of securing the desired peace and prosperity was by technocratic elite-led guidance. $I d$.

${ }^{114} I d$. at 6 . The Schumann Declaration is an early expression of this tendency towards European integration from the top down: whereby the economic union of Germany and France through a coal and steel trading relationship would create the "first concrete foundation of the European Federation which is indispensable to the preservation of peace." Bignami, supra note 8 at 120 (citing Robert Schumann, Paris Declaration of May 9, 1950).

${ }^{115}$ Case 120/78, Rewe-Zentral v. Bundesmonopolverwatung Fur Branntwein, 1979 E.C.R. 694, at para. 14.

${ }_{117}^{116}$ European Commission, Completing the Internal Market, 1985, COM(85) 310 final.

${ }^{117}$ Helmut Schmitt von Sydow, The Basic Strategies of the Commission's White Paper, in 1992:ONE EUROPEAN MARKET? 96 (Bieber et al. eds., 1988).

${ }^{118}$ Giandomenico Majone, The European Community: An "Independent Fourth Branch", in VERFASSUNGEN FUR EIN ZIVILES EUROPA 23, 34 (Gert Bruggemeier ed., 1994).
} 
were more willing to cede regulatory authority to a supranational regulator where the transaction costs of coordination among independent actors were too high. ${ }^{119}$

A problem in ceding regulatory authority to a Community authorities arises in the context of Member States communicating normative regulatory preference, however: there is a risk of the system becoming deligitimized. ${ }^{120}$ The very political sensitivity of GMO regulation, and the grassroots opposition deliberate release has generated in many Member States, counsels against a pure Community driven system, at least in the normative sense. ${ }^{121}$ In support of this assertion, a parallel can be drawn with the WTO's history of "regulating" environmentally sensitive trade issues. The WTO's version of neo-functionalism, which John Ruggie dubbed the "embedded liberalism bargain,"122 acted with the same driving belief, that a technocracy built of institutional experts sitting outside the political system would ultimately be more effective than incorporating

${ }^{119} I d$. at 37. Daniel Halberstam has examined the differences between U.S. and European attitudes towards centralized regulation in the form of commandeering, pointing out that in Printz v. United States, Justice Stephen Breyer observed in his dissenting opinion:

The federal systems of Switzerland, Germany, and the European Union, for example, all provide that constituent states, not federal bureaucracies, will themselves implement many of the laws, rules, and regulation, or decrees enacted by the "federal" body...They do so in part because they believe that such a system interferes less, not more, with the independent authority of the "state", member nation, or other subsidiary government...

Daniel Halberstam, Comparative Federalism and the Issue of Commandeering, in THE FEDERAL VISION: LEGITIMACY AND LEVELS OF GOVERNANCE IN THE US AND THE EU 215-6 (Kalypso Nicolaidis \& Robert Howse eds., 2001) (quoting Printz v. United States, 521 U.S. 898, 976-77 (1997)).

${ }^{120}$ ELLEN VOS, INSTITUTIONAL FRAMEWORKS OF COMMUNITY HEALTH AND SAFETY LEGISLATION: COMMITTEES, AGENCIES, AND PRIVATE BODIES 94-5 (1999)(arguing that in "legal science", acceptance of rules stems from a feeling that the rules are just and the institutions promulgating them are legally authorized to make them).

${ }^{121}$ In terms of the political sensitivity for instance, when the Commission in the Greenpeace France case approved the release of the GM maize, it did so despite opposition by 13 Member States. See KRÄMER, supra note 34 at 239.

${ }^{122}$ John Ruggie, Embedded Liberalism and the Postwar Economic Regimes, in CONSTRUCTING THE WORLD POLITY: ESSAYS ON INTERNATIONAL INSTITUTIONALIZATION 62 (1998). The embedded liberalism bargain was essentially a grand scale rationalization of the problems associated with conflicts between trade liberalization and the GATT member's initial commitment to a "progressive, interventionist welfare state" which would include domestic regulation of environmentally sensitive areas. JOOST PAUWELYN, CONFLICT OF NORMS IN PUBliC INTERNATIONAL LAW, HOW WTO LAW RELATES TO OTHER RULES OF INTERNATIONAL LAW 34 (Cambridge University Press, 2003). 
normative regulatory preferences of members. The guiding justification for embedded liberalism was that for some period of time, the difficulties normative regulatory preferences would be rationalized as manageable by technocrats and experts within the trading system. ${ }^{123}$ Embedded liberalism allowed the WTO to function without a grand normative vision such as protecting the environment, protecting human rights, etc. But at the hands of trade policy elite, embedded liberalism became recast as a normative ideology of free trade: the removal of market distorting trade barriers enhanced aggregate domestic welfare. ${ }^{124}$ This normative preference threatened the legitimacy of the entire system. $^{125}$

While Community regulatory tendencies may not fall into the same "technocracy trap" $" 126$ that the WTO did, as the system is older and wiser in many regards, and certainly Community regulatory policy is not at risk of a race to the bottom ${ }^{127}$, at the same time with a highly sensitive and politically charged issue like GMOs, even a hint of normative ambition within a technocratic regime could be disastrous. While Community regulators have promoted European regulatory solutions using criteria acceptable throughout the Europe, specifically scientific assessment, risk assessment is not a task solely performed

\footnotetext{
${ }^{123}$ Robert Howse, From Politics to Technocracy - And Back Again: The Fate of the Multilateral Trading Regime, 96 AM. J. INT’L L. 94, 96 (2002).

${ }^{124}$ Id. at 99. See also Joseph Weiler, The Rule of Lawyers and the Ethos of Diplomats: Reflections on the Internal and External Legitimacy of Dispute Settlement, in EFFICIENCY, EQUITY, AND LEGITIMACY: THE Multilateral Trading System at the Millenium 334, 336-37 (Roger B. Porter, Pierre Sauvé, Arvind Subramanian \& Americo Baviglia Zampetti eds., 2001).

${ }^{125}$ See, e.g., Pollack \& Shaffer, supra note 11 at 170 (discussing the political fallout from the anti-WTO demonstrations at the Seattle ministerial meeting).

${ }^{126}$ This term is borrowed from Christian Joerges, who uses it in a somewhat different context. See Christian Joerges, 'Deliberative Supranationalism'-Two Defences, 8 EUR. L.J. 133, 134 (2002).

${ }^{127}$ Christian Joerges, Paradoxes of deregulatory strategies at Community level: The example of Product Safety Policy, in DEREgulation OR REREgulation?: REgulatory REFORM IN EUROPE AND IN THE UNITED STATES 176 (1990).
} 
by experts. ${ }^{128}$ Broader social developments, cultural traditions and values should be respected as well. ${ }^{129}$ The increasing use of framework directives, as opposed to regulations, encourages Member State flexibility and some degree of autonomy. ${ }^{130}$ The results of a neo-functional style approach to GMO regulation, however, could be just as politically $\operatorname{costly}^{131}$ as embedded liberalism has turned out to be for the WTO, particularly in light of the upcoming referendums on the Constitutional Treaty. ${ }^{132}$

\section{B. Regulatory Anarchy - A Uniquely European Solution}

Regulatory anarchy shares with neo-functionalism the notion that integration should be incremental, with previous cooperative regulatory successes building momentum for future cooperative regulations. ${ }^{133}$ The major difference is that this cooperation happens as between national regulators rather than between supranational officials or interest groups. ${ }^{134}$ Regulatory anarchy moves away from a true federalist system, with integration consisting of communication between twenty-five individual administrative and political systems rather than one federalist system where constituent states administer the central government's laws. ${ }^{135}$

\footnotetext{
${ }^{128}$ Vos, supra note 120 at 95; CARL F. CRANOR, REGUlATING TOXIC SUBSTANCES: A PHILOSOPHY OF SCIENCE AND LAW 131 (1993).

${ }^{129} \mathrm{Id}$

${ }^{130}$ Joanne Scott \& David M. Trubek, Mind the Gap: Law and New Approaches to Governance in the European Union, 8 EUR. L.J. 1, 2 (2002).

${ }^{131}$ Philippe C. Schmitter points out that in hindsight, neo-functionalism generally misjudged the role of politicization, weakening rather than strengthening pan-European political parties. Philippe C. Schmitter, Neo-Functionalism, in EUROPEAN INTEGRATION THEORY, supra note 106 at 56.

${ }^{132}$ For a history of the European Union integration from the 1950s until the birth of the Constitutional Treaty, see J.H.H. WEILER, THE CONSTITUTION OF EuROPE, "Do THE NEW Clothes HAVE AN EMPORER?" AND OTHER ESSAYS ON EUROPEAN INTEGRATION 10 (1999).

${ }^{133}$ Bignami, supra note 8 at 121.

${ }^{134} I d$.

${ }^{135} I d$. This system of negotiation has also been called "loose coupling" when applied in national parliaments - “"critical dialogue between government and majority faction' proved to be an efficient instrument of political concertation.” Jachtenfuchs \& Kohler-Koch, supra note 106 at 104.
} 
Bignami points out that when regulators bargain to a successful result, thereby obviating the need for Community interference on the part of the ECJ or the Commission for instance, the regulators are interpreting the Treaty article, the Directive, the standards, and the application of the standards. ${ }^{136}$ Put in another way, the national regulators negotiate everything "from the constitutional article, to the legislation, to the administrative rules, to the enforcement of those rules." 137 This is a particularly powerful position within the European framework, particularly because, outside of their own national governments, there is no "European Prime-Minister" to put pressure on individual regulators to move in one direction ${ }^{138}$ and regulators are free to devise universally acceptable normative preferences. This unsupervised, unmitigated potential for conflict, accurately termed "anarchy," 139 may ensure a fostering of what Daniel Halberstam calls "liberal fidelity" - where different units of government working to ensure the proper functioning of the whole, engage in democratic struggle and debate, leading to valuable safeguards of liberty and concrete, positive policy outcomes as well. ${ }^{140}$ Bignami uses the example of the Television Without Frontiers Directive ${ }^{141}$ : "national regulators agreed, in the text of the directive, to periodically review its application and to negotiate more precise terms where experience showed that national

\footnotetext{
${ }^{136}$ Bignami, supra note 8 at 110.

${ }^{137} \mathrm{Id}$.

${ }^{138} I d$.

139 "Anarchy" in this sense, then, is not the Hobbseian vision of international relations, Bignami, supra note 8 at 101, but rather as Elinor Ostrom has explained, an organizing model based on users cooperating to the most efficient result. See Elinor Ostrom, Governing THE COMMONS: ThE Evolution of InstituTiOnS FOR COLLECTIVE ACTION 61-102 (1990). The link between both conceptions of anarchy is a decentralization of authority and a positivie response to credible commitments.

${ }^{140}$ Daniel Halberstam, Of Power and Responsibility: the Political Morality of Federal Systems, 90 VIRG. L.R. 731, 734, 737 (2004).

${ }^{141}$ Council Directive 89/552/EEC of 3 October 1989 on the coordination of certain provisions laid down by Law, Regulation, or Administrative Action in Member States concerning the pursuit of television broadcasting activities, [1989] OJ (L 298/23).
} 
regulatory differences continued to block free circulation of programming."142 Thus, while the framework directive and accompanying legislation outlines in broad strokes how regulatory bodies are meant to act, and this is enforced at a Community level, the detailed terms of the function of the regulatory regime are negotiated on an intra-Member State level. ${ }^{143}$

The regulatory anarchy approach is particularly well suited to the current biotechnology regulatory debacle. If the current regime was re-engineered so that the initial approval process did not involve one Member State but rather a consortium of regulators, negotiating to the most acceptable result (with the assumed trade-offs over time as Bignami envisions), this would solve the problem of one Member State capturing the process and also ensure that there is no perceived Community level insensitivity.

Since the enactment of the Deliberate Release Directive, the Community has moved towards instruments that approximate an idea of regulatory anarchy, particularly the Food and Feed Regulation. ${ }^{144}$ The approval process in the Food and Feed Regulation is different from the Deliberate Release Directive in the crucial first step of the application for release. Like in the Deliberate Release Directive, the applicant under the Food and Feed Regulation must start the process by submitting an application to the Member State authority. ${ }^{145}$ Unlike in the Deliberate Release Directive, however, at the time of application the Member State must immediately forward the dossier on to the

\footnotetext{
${ }^{142}$ Bignami, supra note 8 at 107.

143 Anne-Marie Slaughter points to this "regulation by networks" and the comitology procedure in the EU as an example of her broader theory that international institutions in general are moving towards a new model of transgovernmental networks. See AnNe-Marie SLAughter, A New World Order 40, 43 (2004).

${ }^{144}$ Food and Feed Regulation, supra note 59. The Food and Feed Regulation only regulates GMOs in food and feed and is therefore more limited in scope than the Deliberate Release Directive.

${ }^{145}$ Id. at art. 5(2).
} 
European Food Safety Authority ${ }^{146}$ (EFSA) and other Member States. ${ }^{147}$ At this point, the EFSA, and not the initial Member State, oversees the risk assessment, only conferring with the Member State authority in select instances. ${ }^{148}$ The EFSA acts as a hub in an interactive network between Member States, the Commission, and industry. ${ }^{149}$ The EFSA is primarily composed of Member State representatives chosen by a collaborative process between the Council, Commission, and the Parliament. ${ }^{150}$ The advantage of EFSA oversight ${ }^{151}$ is that the Member States can credibly commit themselves to longterm environmental and consumer-protection goals before the approval process is engaged. ${ }^{152}$ Delegated authority in this system is advantageous to Member States pursuing long term goals, and certainly the assessment powers of individual Member States are diminished in the initial stage of the process. ${ }^{153}$

Because the costs of defection of non-compliant Member States from a regulatory system are high in the context of GMOs, it is likely that national regulators will be willing to cede some power to Community level institutions in exchange for control over

\footnotetext{
146 The EFSA was established pursuant to Regulation 178/2002, [2002] OJ (L 31). For a background of the establishment of the EFSA, see Damian Chalmers, Food for Thought: Reconciling European Risks and Traditional Ways of Life, 66 MoDERN L.R. 532, 534-8 (2003); Keith Vincent, "Mad Cows" and Eurocrats: Community Responses to the BSE Crisis, 10 EUR. L.J. 499 (2004).

${ }^{147}$ Food and Feed Regulation, supra note 59, at art. 5(2)(a),(b).

${ }^{148}$ Id. at art. 6(3).

${ }^{149}$ Damien Chalmers, Risk, Anxiety and the European Mediation of the Politics of Life: The European Food Safety Authority and the Government of Biotechnology, Paper Presented to the Harvard European Law Association 3 (Oct. 29, 2004), available at http://www.law.harvard.edu/programs/elrc/events/socialregulation.pdf.

${ }^{150}$ Regulation $178 / 2002$, at $\$ 2$.

${ }^{151}$ For a discussion of the importance of the independence of a agents within the Community regulatory framework, see generally GIANDOMENiCO MAJONE, REGULATING EUROPE (1996); Giandomenico Majone, Two Logics of Delegation, 2 EUR. UNION POLITICS 103 (2001); Giandomenico Majone, Nonmajoritarian Institutions and the Limits of Democratic Governance: A Political Transaction-Cost Approach, 157 J. INST. THEORETICAL ECON. 57 (2001).

${ }^{152}$ Sebastian Krapohl, Credible Commitment in Non-Independent Regulatory Agencies: A Comparative Analysis of the European Agencies for Pharmaceuticals and Foodstuffs, 10 EUR. L.J. 518, 523 (2004).

${ }^{153}$ Brosset, supra note 16 at 576.
} 
enforcement in other parts of the system. ${ }^{154}$ This action is partially a response to the need for credible commitments to a unified regulatory approach. ${ }^{155}$ In another cross-over from neo-functionalism, by creating a Community level Member State negotiating process, regulatory transaction costs are also reduced for individual Member States.

It is important to note that the protection of national interests is not necessarily maintained by reserving a specific degree of competence to the national authorities. ${ }^{156}$ At the same time, if a high degree of Member State representation within the Community institutions responsible for risk assessment is maintained, as is the case with the EFSA, the centralization of the procedure around Community institutions does not necessarily have to lead to a centralization of the procedure per se. ${ }^{157}$ In addition, as discussed above, the Commission can only make a final decision on a deliberate release if the Council fails to give a ruling. ${ }^{158}$ Estelle Brosset postulates that it is this part of the process whereby Member States maintain meaningful and collaborative control of the process: "[T]he decision about risk management would stay firmly in the hands of the Member States, represented under the auspices of the Council, and they would therefore

${ }^{154}$ Bignami, supra note 8 at 101. See also, Harold H. Koh, Transnational Legal Process, 75 NEB. L.R. 181, 199-200 (1996)

$[\mathrm{N}]$ ations are not exclusively preoccupied with maximizing their power vis-à-vis one another in zero-sum games. Rather they employ cooperative strategies to pursue a more complex and multi-faceted long-run national interest, in which compliance with negotiated norms serves as a winning strategy in a reiterated 'prisoners dilemma' game. Game theory predicts that states, as rational, self-interested actors, will pursue a variety of strategies to achieve both short- and long-term gains, depending on the relative costs and benefits of competition, cooperation, or "defection" from a cooperative scheme.

Id. (emphasis in the original).

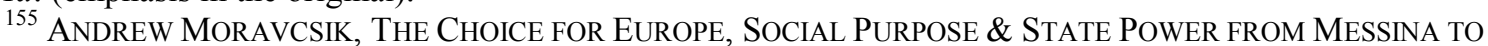
MAASTRICHT 73 (1998)(“Governments are likely to accept pooling or delegation as a means to assure that other governments will accept agreed legislation and enforcement, to signal their own credibility, or to lock in future decisions against domestic opposition.")

${ }^{156}$ Brosset, surpa note 16 at 577.

${ }^{157} \mathrm{Id}$.

${ }^{158}$ Food and Feed Regulation, supra note 59 at arts. 7, 19, 35. 
have the possibility of definitively preventing a product from being placed on the market, whilst at the same time acting collectively and legitimately." 159

Admittedly, the parallels between a pure regulatory anarchy (where a consortium of independent regulatory states drives the process incrementally) and the Food and Feed Regulation (which allows for independent non-Member State oversight at the initial stages followed by potential Member State input through the Council at a later stage) are not exact. The Food and Feed Regulation, however, carries the promise of real dialogue and negotiation among competing regulatory authorities and approaches. This stands in stark opposition to the Deliberate Release Directive which allows unfettered choices for individual national regulators, with adverse consequences for all other national regulators.

The goal of this exercise is to conceptualize a way for the GMO regulatory system to function smoothly and maintain political accountability. The Member State input at the beginning of the approval process is arguably the most problematic part of the Deliberate Release Directive because it allows one Member State's regulatory preferences to decide for all. As well, this first stage of the approval process has allowed Member States to effectively ban GMOs from entering the Community. A revamped system such as the Food and Feed Regulation whereby initial approval competence is preserved at the Community level may alleviate these problems, however Member State input and the opportunity to negotiate among regulators should be spelled out in a more meaningful way than the indirect input method provided by Council representation in the Food and Feed Regulation.

\footnotetext{
${ }^{159}$ Brosset, supra note 16 at 578.
} 


\section{Conclusion}

The problem of GMO regulation is largely a problem of regulatory gridlock. The gridlock is complicated however by the fact that GMO release into the Community has captured the minds of Europeans in a way that other regulatory objectives have not. Further complicating matters is the nature of GMO release, particularly the fact that GMOs can travel across national borders independently (i.e. they do not respect national borders) and once they are released into the environment, it is not clear that they can be effectively removed. All of this requires a system whereby decisions can be made in a collaborative way, respecting the needs of civil society in individual Member States while still preserving the regulatory efficiency essential to integration. By embracing the horizontal, anarchic regulatory tendencies which an integrating Europe has tended towards, rather than top-down neo-functionalism, the European Union may move closer to an efficient and acceptable system of GMO regulation. Indeed, the seeds have already been sown in new legislation like the Food and Feed Regulation. 